\title{
THE KNOWLEDGE ECONOMY AS A PARADIGM OF THE ESTABLISHMENT AND DEVELOPMENT OF POST-INDUSTRIAL SOCIETY
}

\section{Matiuk T. V.}

\section{INTRODUCTION}

The current state and prospects of development of the national economy are the result of the interaction of two objective processes. On the one hand, it is the influence on the trajectory, quality and changes rate in a society of the whole set of national specific traits of political, cultural, social, economic and institutional nature, which determine and will determine in the future peculiarities of the socio-economic evolution of the country. On the other hand, it is the dependence of nation-states on the tendencies of the development of the world economy, whose significant influence on the quantitative and qualitative indices of the functioning of the countries of the world has been greatly enhanced by the expansion of globalization processes.

The Ukrainian economy is also under the significant influence of interrelated processes. On the one hand, the negative "legacy" of the former administrative-command model of development, the complexity of market reforming of the economy, certain missteps of the economic policy of the state, etc., determines the contradictory tendencies of modern relations in the country. On the other hand, in the modern context, each country has a clear set of guidelines for further development taking into account the advanced trends of world evolution, which are associated with the transition of leading countries to post-industrial society. Therefore, an alternative to the further motion of countries is a combination of their sustainable traditions with the best that has emerged in world practice. In other words, it involves the need for development to meet the needs of modern post-industrial civilization.

\section{Theoretical frameworks of the study of the knowledge economy}

One of the key characteristics of global changes today is the development of the knowledge-based economy. Even though education, inventions, knowledge accumulation have been important features of 
progress throughout world history but power and wealth have been the main sources of authority. At the modern stage, this balance is broken and, as A. Toffler rightly says, there are power metamorphoses which cause "strong dependence of power and wealth on knowledge".

The term "the knowledge economy" occurs more frequent in foreign and domestic research and is used to define the type of economy where knowledge plays a decisive role and knowledge production is a source of growth. Today, the knowledge economy in the broadest sense includes four main spheres: 1) R\&D and innovation; 2) education and training which contribute to the formation of human capital assets; 3 ) computer information technology (CIT); 4) high-quality production.

Although each of these spheres preserves their relative autonomy, their interrelation is clear. In fact, there is an increasing convergence of three different spheres of social activity, since diffusion of information technologies into other spheres is impossible without the appropriate level of professional training of developers and minimal information literacy of users. Besides, to open up new applied opportunities for CIT, it is necessary to have new scientific knowledge and mechanisms to transform the knowledge into commercial products - goods and services. For this very reason, it is essential to refer to the knowledge economy as the most important for the development and to information society as a whole.

Today, economic theory doesn't have a well-established concept of the category "the knowledge economy". J. Schumpeter, F. Hayek, and F. Machlup laid the foundation of the knowledge economy. Thus, F. Machlup $(1962)^{2}$ considered the knowledge economy as the economic sector where knowledge plays a decisive role and knowledge production is a source of growth; moreover, he also highlighted the active growth of the relevant economic sector. According to calculations of the scientist, in 1958, the knowledge economy sector was $29 \%$ of U.S. gross domestic product. F. Machlup attributed the following five types of activities to the relevant sector: education, research and developments, mass media (radio, TV broadcast, telecommunication and others), IT, information

1 Тоффлер Э. Метаморфозы власти: Знание, богатство и сила на пороге XXI века / [Пер. с англ. науч. ред., предисл. П.С.Гуревича]. Москва: ООО «Издательство АСТ», 2002. 670 с.

2 Machlup F. The production and distribution of knowledge in the United States. Princeton: Princeton University Press, 1962. 416 p. 
services. However, due to the expansion of the so-called "knowledge sector" in the context of the greatest economic growth achieved through research and innovation, the term "knowledge economy" has gained a new meaning. Thus, "the knowledge economy" or "knowledge-based economy" is considered as the type of economy where knowledge plays a pivotal role. That kind of the term's meaning was popularized by P. Drucker. In his book "The Age of Discontinuity: Guidelines to our Changing Society" (1968 p.) $)^{3}$, the author considered using knowledge for the production of economic goods. He came to grips with the issue of what resource is central in the modern economy. P. Drucker argued that physical, financial and managerial resources are not the decisive factors of production. Based on the above, he defined the knowledge economy as a special type of economy where knowledge plays a decisive role, and their production became a source of economic growth and competitiveness. Since the mid-1990s, the concept of the knowledge economy has been actively developed by many economists from around the world and has been supported by such reputable organizations as the United Nations, the Organisation for Economic Co-operation and Development (OECD), the World Bank and United Nations Educational, Scientific and Cultural Organization (UNESCO), as well as by the socio-political elite of almost all developed countries and some developing countries. In the UN experts view, the knowledge economy is economy where knowledge is formed, spread and used for providing economic growth and international competitiveness of the country. At the same time, knowledge enriches all industries, all sectors and all participants in economic processes. In the broadest sense, the concept of the knowledge-based economy is economy where information and knowledge based on it occupy a top-priority position. The basis of that kind of economy is the creation, dissemination and use of knowledge to ensure its sustainable development and competitiveness. The knowledge economy is also a type of economy where the very generation and use of knowledge plays a dominant role in the creation of prosperity; however, human capital becomes the center of economic activity of economic entities. In the late nineties, the concept "the knowledge economy" got the most widespread use.

\footnotetext{
${ }^{3}$ R. L Katz. New York : Praeger, 1988. 168 p.
} 
The development of the knowledge economy and determination of the knowledge influence on the economic activity of particular business entities takes place within the study of human capital structure. Knowledge, as an integral part of human capital, is considered in modern economic science in the context of such research lime as human capital theory. The creation of the theory can be interpreted as one of the most remarkable events.

Modern society is the knowledge society, and for this reason, the more recent attention has been paid to the knowledge-based economy as a key to the establishment and development of post-industrial society, the development of economic relations and the improvement of the quality of living standards. To ensure the development under the conditions when the information and the knowledge obtained on its basis become one of the main objects of management, there is a challenge to develop and apply new management methods that will turn the knowledge into a unique product and the main strategic resource for the development of all economic entities.

The knowledge economy is characterised not only by the development of high technologies but, first of all, by effective mechanism of knowledge production, that is appropriate education system, communication system, fundamental and applied science, patent system and awareness-raising activities on the development of that kind of economy, ensuring high living standards of the population for human potential development, because it is the very factor contributes to the establishment of a post-industrial society at the present stage of economic transformation.

Modern education has to meet the main parameters of the emerging post-industrial civilization. In the book "Future shock", A. Toffler marks that a new strategy is a re-orientation of the education system that will guarantee "soft landing in the future" for the new generation". The modern approach needs the issue regarding the new human image as an education result.

Today, the world needs not just a person who knows but who understands. Education in the modern world is considered not as the final product of one of the stages of human life but as a constant and dynamic process. In the past, education was limited by a well-defined and quite

${ }^{4}$ Тоффлер А. Футурошок - СПб. : Лань, 1997. 464 с. 
short period of working life after which a person gave up the education system and rarely came around to study again. In the context of current fast time, the rapid obsolescence of knowledge necessitates their constant updating and periodic improvement of educational background. Since birth, learning continues actually throughout human life.

In going from the traditional to a new level, a man finds out and keeps the ability to establish cause-effect relations, to get to the root of socio-economic processes, phenomena; to find original and at the same time simple fix; to synthesize available knowledge in a new system. As such, it is necessary to put your problems into the rank of tasks which are easy to fix, that is, to make your life and business trouble-free.

A man who thinks is a product of traditional education systems, and thinking man (that is a wise man) is a product of ultramodern education system. A smart person always finds a way out of any complicated situation, and the main target of ultramodern education systems is to bring up a wise person who can predict and prevent the origin of challenges. Traditional and ultramodern education systems laconically complement each other. The old education system provides general knowledge, and new one teaches how to use gained knowledge and skills as effectively as possible for solving particular problems.

Thus, the efficiency of modern physical output and scientific and technological progress are directly dependent on, among other factors, the general development of knowledge and skills of workers. Within this context, the education system, acting as the key link in the process of reproduction of the total workforce, plays a growing role in the social, economic and scientific and technical development of the country.

At the same time, the modern rapid development of the information society outstrips the possibilities of meeting the demand for professional training. Education establishments are now training students for work that is not available yet using day-old technology. Thus, according to international experts, 10 most sought after professions in 2010 did not exist in 2004. As the amount of new scientific and technical information doubles every 2 years, for students studying 4 years, it means that half of what they study will become obsolete by the end of the third year of study.

It is clear that in the post-industrial era, dynamics and transition rates of the economy to the knowledge economy mainly depend on the efficiency of using the results of human creative activity. For this reason, one of the main challenges which need constant attention is the creation of 
an effective system of production, protection, reproduction and use of the intellectual potential that requires corresponding changes in the education system. The very education as the system of formation of the intellectual capital of the people and as one of the main spheres of innovation production creates basic conditions for rapid development of an economy based on achievements of scientific and technological progress.

As the knowledge economy is considered to be the most important condition for socio-economic development, its diagnostics through specially developed knowledge economy index becomes an essential component for studying the evolution of economic and education systems. Methodology for index calculation is a reproduction of institutional development concepts, which show that the transition of the countries' economy to the post-industrial stage of development is impossible without the institutional changes and high quality of education that causes the changes.

Table 1

EBRD 2018 Knowledge Economy Index - performance by economy

\begin{tabular}{|c|c|c|c|c|c|c|}
\hline Economy & 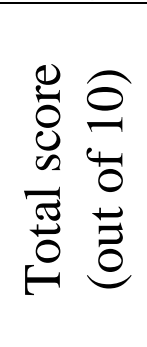 & 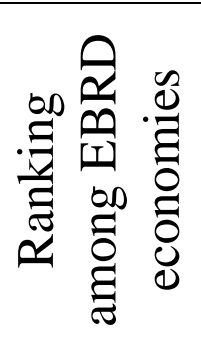 & 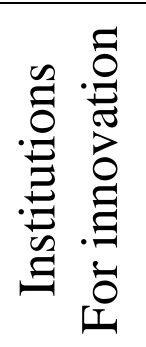 & 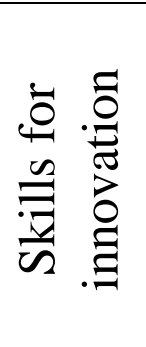 & 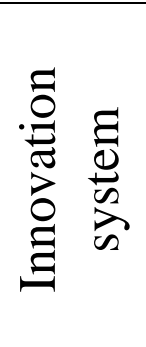 & 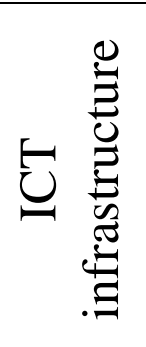 \\
\hline Estonia & 6.82 & 1 & 8.01 & 6.70 & 4.58 & 7.99 \\
\hline Poland & 5.63 & 6 & 6.80 & 6.31 & 3.82 & 5.58 \\
\hline Hungary & 5.33 & 9 & 6.55 & 5.82 & 3.49 & 5.47 \\
\hline Romania & 5.01 & 15 & 6.02 & 4.94 & 3.41 & 5.68 \\
\hline Turkey & 4.60 & 19 & 4.87 & 4.81 & 3.82 & 4.90 \\
\hline Belarus & 5.21 & 11 & 5.50 & 6.05 & 3.27 & 6.01 \\
\hline Ukraine & 4.29 & 27 & 4.33 & 5.44 & 2.84 & 4.56 \\
\hline
\end{tabular}

Source $^{5}$

In the above rating, Ukraine takes $27^{\text {th }}$ place among other 37 world countries. Therefore, the approximation to the knowledge economy as a

5 Індекс економіки знань: веб -сайт. URL: file://C:/Users/User/Downloads/ebrdknowledge-economy-index.pdf 
component of postindustrial civilization through the direct and immediate way is linked to the formation of qualitative characteristics of social consciousness as one of the main factors in the formation of an effective institutional environment that contribute to innovative development.

Thus, indices data show that Ukraine takes a relevant position, first of all, due to the low index of the Innovation system, which is 2.84 .

In this context, it is essential to consider the level of economic, political and civic culture of Ukrainians, which is largely shaped by education. The latter establishes knowledge about the patterns of society's development in the unity of its economic and political spheres, changes people's visions of how to achieve better living conditions and their self-development. As a consequence, education changes people's concept of what government should be and what policy it should pursue to promote development.

Effective democracy in any country is based on active citizens. However, "uneducated society cannot effectively exercise collective selfdetermination. In order to have a strong democratic public position in relation to any social problem, people must comprehend the relevant concepts, principles, policy, procedures, ethical standards and certificates" $"$.

The lack of comprehension of interconnection between education and democracy and public activity in the consciousness of many Ukrainians, and especially young people, that causes passivity of the youth in forming fundamentals of extending rights and opportunities as a necessary component of the development. Only $1.5 \%$ of young Ukrainians work in public organisations and unions while in countries like Austria, Denmark, Belgium, Finland, Sweden, this proportion covers about $25 \%$ of young people ${ }^{7}$.

In general, the execution of functions by the economy of Ukraine doesn't meet the requirements of the postindustrial stage of human evolution fully. The relatively high level of the population literacy is not

${ }^{6}$ Демократизация глобальной экономики. Роль гражданского общества. Доклад центра изучения глобализации и регионализации университета г. Варвик: пер. на рус. яз. Л. Проскуряковой, 2003. 128 с. URL: http://warwick.ac.uk/fac/csgr/projects/ russianreport.pdf.

7 Українське суспільство 1992-2012. Стан та динаміка змін. Соціологічний моніто-ринг / [За ред. В. Ворони, М. Шульги]. Київ: Інститут соціології НАН України, $2012.348 \mathrm{c}$. 
characterised by an adequate quality of economic and human development and does not stimulate innovation. That sort of situation retards the rate of positive changes in the society and requires the relevant reforming in the aspect of conformity in requirements of the knowledge economy.

\section{Peculiarities of the development of postindustrial society under modern conditions}

Efforts of the founders of the theory of post-industrial society focused on identifying the characteristics of a new society. Research of D. Bell, H. Kahn, R. Dahrendorf led to careful thought of fundamentally different kind of society. Researchers consider the basis of the changes in enhancing the role of science. In their view, the potential for the development of that sort of society is determined by the scale of information and knowledge it possesses.

D. Bell, clearing up the novelty of modern sources of economic growth, recalled that land, capital and labour had been considered as the main factors of production for the industrial era for a long time. W. Sombart and J. Schumpeter enhanced the triad with such important concepts as "entrepreneurship" and "business initiative". However, D. Bell noted that "when knowledge in its systematic form is involved in the practical processing of resources (in the form of the invention or organizational improvement), one can say that the very knowledge, not labour, is the source of value" "With the reduction of working time and the role of manufacturing worker, it becomes clear that the knowledge and methods of its practical use replace labour as a source of added value. In this sense, labour and capital were central variables in industrial society, and information and knowledge became decisive variables in post-industrial society"

P. Krugman marks that "property is no longer the determining basis of elite status. Multibillionaires earn most of their income in the form of remuneration for their work",

8 Белл Д. Грядущее Постиндустриальное общество: опыт социального прогнозиро-вания / Перевод с английского Иноземцев В. Л. Изд. 2-ое, испр. и доп. Москва: Academia, 2004. 788 с.; Гальчинський А. С. Економічна методологія. Логіка становлення. Київ: «АДЕФ - Україна», 2010. 572 с.

${ }^{9}$ Krugman P. R The Conscience of a Liberal. W.W. Norton \& Co., 2007. 352 p. 
Thus, if land ownership, buildings, factories, machines, production means were the main physical element for industrial society, intangible substance became the basis of ownership under passing to postindustrial society ${ }^{10}$.

The situation in the new economy is that instead of land pressure, investment and capital, there is an excess of cash capital and production capacity. The most popular and desirable resources are a man and his intellect, whose properties significantly differ from traditional means of production. At the same time, the structure of socio-economic relations is changing as a new form - intellectual property, and a new dominant social group - the owners of knowledge appear to replace ownership of the means of production and land ownership". A. Toffler notes that "the most significant form of ownership is now imponderable. It is supersymbolic. It is knowledge. It can be simultaneously used by many people to create welfare and to produce new knowledge"12.

Spiritual ownership is fundamentally different from private one because it can develop only as an individual-personal and, at the same time, as public ownership. Its extended reproduction is mainly not on a commercial basis. It is directly related to the development of personal wealth and the accumulation of the spiritual (intellectual) potential of the whole society, and indirectly - to the accumulation of capital ${ }^{13}$.

Indeed, one of the main features of the new economy is the transition from the domination of material goods production (industrial economy) and the rapid development of the service sector (post-industrial economy) to the emergence of multifunctional information technologies, which in economic terms made it possible to intensify the processes of development of post-industrial economy significantly, in technical terms - to minimize the time of information transfer to anywhere in the country, and in social terms - to strengthen the role of the human factor and create a significant basis for the establishment of a mixed society. However, in the era of the new economy, the main strategic resource of production -

10 Брежнєва-Срмоленко О. В. Інтелектуальна складова в структурі елементів нової економіки. Актуальні проблеми економіки. 2010. № 3.

${ }^{11}$ Там само.

12 Тоффлер О. Метаморфозы власти: знание, багатство и сила на пороге XXI века / Пер. с англ. Москва: Аспект Пресс, 2004. 400 с.

13 Гальчинський А. С. Економічна методологія. Логіка становлення. Київ: «АДЕФ Україна», 2010. 572 с. 
both tangible and non-tangible one - is a man and his intelligence and skills but not knowledge, service or information. After all, human intelligence is a "productive force of a global scale"14.

If to summarize the characteristics of post-industrial society theory available in the scientific literature (see ${ }^{151617}$ ), they can be narrowed down to three main characteristics: first, the source of productivity and the growth of a new stage of social development is knowledge, information that is processed and extended to all sectors of economic activity through information technology; second, the main type of economic activity is production of services; third, leading role in the social production of professions associated with high intensity of knowledge and information, displacement of labour as a typical type of economic activity in industrial society, a qualitatively new type of activity - creativity.

The economic practice of the last decades has confirmed the findings of the founders of the theory of post-industrial society, as the experience of economic, social, political and cultural development of the leading countries of the world confirms the peculiarity of all these essential features to the realities of the late XX century - the early XXI century. For example, in modern society, the information industry is extremely large. Now, each of us lives in an extremely dynamic, knowledge-based, interdependent information society. This fact is confirmed by development rate of scientific and technological progress worldwide: it took 38 years for a radio audience of 50 million people, 13 years for television, 4 years for the Internet, 3 years for iPod, and only two years for Facebook; international social media MySpace has more than 200 million users, so if MySpace were a country, it would be the fifth country by population. The increase in the number of authorised users is 250 thousand people per day; Google deals with 31 billion search queries

14 Брежнєва-Срмоленко О. В. Інтелектуальна складова в структурі елементів нової економіки. Актуальні проблеми економіки. 2010. № 3.

15 Белл Д. Грядущее Постиндустриальное общество: опыт социального прогнозиро-вания / Перевод с английского Иноземцев В. Л. Изд. 2-ое, испр. и доп. Москва: Academia, 2004. 788 c.

${ }^{16}$ Кастельс М. Информационная эпоха. Экономика, общество и культура. Пер. с англ. под науч. ред О. И. Шкаратана. Млсква:ГУ ВШЭ, 2000. 608 с.

17 Тоффлер Э. Революционное богатство: как оно будет создано и как оно изменит вашу жизнь; [Пер. с англ. М. Султанова, И. Цыркун]. Москва: АСТ; АСТ МОСКВА; Профиздат, 2008. 596 с. 
every month and as far back as 2006, they accounted for 2.7 bn.; growth dynamics in Internet-devices: in 1984 there were 1 thousand pcs, in $1992-1$ million pcs, in $2008-1$ billion pcs; the first commercial SMS message was sent in 1992. Today, the number of messages sent and received per day exceeds the number of people across the globe; experts have found that the "New York Times" issue publishes more information per week than a man received in the 18 th century over a lifetime ${ }^{18}$.

It should be emphasized that along with the growth in information volume, the level of its use also grows. This process was most noticeable in mid-to-late XX century when experts calculated that information volume doubled every 20 months while in the XIX century - during 50 years. Here are the dynamics of the process: from the beginning of A.D., doubling of knowledge took place until 1750, the second doubling was recorded until the beginning of the XX century, the third - until 1950. Then the process of knowledge doubling was more accelerated: until 1970 - for ten years, after 1970 - every 5 years, and since 1991 every year. By the early XXI century, information resources have increased by 250 thousand times ${ }^{19}$. N. Bontis argued that since 2010, the world resources of knowledge and information should double every 11 hours $^{20}$. It is information awareness that determines the educational and professional level of a person that determines its transformation from a biological being to a biosocial owner of knowledge and qualifications. Such owners form an intellectual class that becomes more independent than other social strata of the population ${ }^{21}$.

An agrarian society is based on human interaction with nature, industrial society - on interaction with the transformed nature, and postindustrial society - on interaction between people on the basis of intelligence and information. With the transition from agrarian to postindustrial type of development, the importance of knowledge is steadily increasing. At the same time, there is a shift in the distribution of people by business towards increasing employment in the tertiary sector

18 Грищенко I. М. Освіта та професійна підготовка фахівців у світлі Євроінтеграційних процесів. Актуальні проблеми економіки. 2010. № 7. С. 56-61.

19 Утюж I. Г. Освітній потенціал особистості: Монографія: Запоріжжя: ТОВ «КСК-Альянс», 2007. 147 с.

${ }^{20}$ Bontis N. The strategies Management of Intellectual Capital and Organizational Knowledge. NY.: Oxford University Press, 2002. 740 p.

21 Утюж I. Г. Освітній потенціал особистості: Монографія: Запоріжжя: ТОВ «КСК-Альянс», 2007. 147 с. 
of the economy. Despite the complexity of organizing society and the slowdown in population growth, there is also an increase in life expectancy.

However, it is worth to take into account that economic growth also has detriments to the society. American scientist Mishan E. J., in his paper "The costs of Economic Growth", turned attention to the fact that attempts to achieve economic growth based on technological innovation or to accelerate it significantly will lead to such devastating consequences for the environment that the quality of human life will inevitably take a turn for the worse" 22 . This conclusion made the problem of economic growth limitation actual and raised a concern of the need to solve environmental problems. The author believes that the knowledge economy is one of the mechanisms for the prevention of destroying effects. It contributes to the improvement of environment as it plays an important role in the process of recognition by society of the ominous consequences of physical and biological processes. The very knowledge helps people to realise the need and ability to meet the needs by virtue of available resources without disrupting the balance of the environment developing invention and rationalization, which is the basis for future growth of domestic wealth.

However, growth is not an impulse to development. Therefore, to understand the mechanism of dynamic social changes that are achieved through the knowledge economy, it is necessary to distinguish its function as a factor for the development of the economic system.

First of all, one should pay attention to the fact that economic growth, which is attained through the growth of human and intellectual capital, contributes to increase in incomes of certain population stratum. G. Becker argued that economic growth during the last two centuries is explained by knowledge dissemination that plays a part in the growth of labour and capital as factors of production. In turn, the increasing dependence of production on the knowledge significantly advances human capital. In practice, this is reflected in the increase in remuneration (real income) of highly skilled employees as owners of that type of capital.

In modern conditions, the remuneration is becoming the basis for formation of completely new quality of social power, namely, new middle class. As it is known, the middle class of a mature industrial

${ }^{22}$ Mishan E. J. The costs of Economic Growth: Oxford University Press, 1993. 256 p. 
society consisted of such segments of the population as small entrepreneurs, businessmen, artisans, that is, groups of the self-employed population - petty bourgeoisie. Near $60 \mathrm{~s}-70$ s of the XX century, it was formed new class which involved groups of highly-paid employees: managers, freelancers, academics, educators and media professionals, trade and engineers, teachers, civil servants ${ }^{23}$.

If the traditional middle class was the owner of the means of production, then the representatives of the new middle class own the human capital the dividends of which bring them a basic profit. Like the regular employee, the owner of the human capital possesses labour, however, the employer pays him the basic part of the income not for physical and intellectual abilities, but for the capital at his disposal. The more complex human capital is as a resource for production (education, experience, skills, reputation, etc.), the more it acquires rarity and, respectively, increases in the labour market price.

Thus, the knowledge economy is the most important factor in increasing the level of personal income of those categories of population that are today forming the new middle class.

The income of the middle class improves its value to society as a consumer, as well as an entity that accepts and sets patterns (models) of consumer behaviour. The specific nature of the new middle class is to deal with productive activity which provide the functioning of highperformance modern productions, carries creative and productive functions. Human capital also makes its bearers active participants in civil relations, a relatively independent social force. As a result, the new middle class plays the role of a stabilizer, a function of consolidation in the society of integrative processes and development of social partnership. Human capital also makes its bearers active participants in civil relations, a relatively independent social force. As a result, the new middle class plays the role of a stabilizer, a function of consolidation in the society of integrative processes and development of social partnership. Human capital also makes its bearers active participants in civil relations, a relatively independent social force. As a result, the new middle class plays the role of a stabilizer, a function of consolidation in the society of integrative processes and development of social

${ }^{23}$ Шкаратан О. И., Ильин В. И. Социальная стратификация России и Восточной Европы: сравнительный анализ. Москва: Изд. дом ГУ ВШЭ, 2006. 468 с. 
partnership. Therefore, the knowledge economy, as a major factor in human capital, contributes to income growth and the formation of the middle class as a leading social power and factor of development.

One of the greatest obstacles for sustainable and stable development is inequality. Economic theory and practice have conclusively proved that uncontrolled and deep income differentiation is a direct threat to stability of the society. According to the Pareto principle, if the distribution of low incomes is subjected to acute and unexpected fluctuations then when it is reached their higher level, it gains stability ${ }^{24}$. Thus, social stability of the society as one of the main conditions for its development is a result of high level of the personal sector.

The knowledge economy contributing to the growth in prosperity through the receipt of dividends from human capital influences income equalization and promotes social equality. In fact, it dissolves social barriers as it increases the social status of the individual and, as a consequence, reduces the gap between the majority and the elite in society. As P. Krugman says "property is not a determinative basis for the elite status any more. Multi-billionaires earn a large share of their income in the form of benefits for their work" 25 . Consequently, the knowledge economy plays an important role in providing economic development, on the one hand, influencing stability of society and, on the other hand, creating social force which is objectively interested in social transformation and progressive development in social production and revenue sharing.

Meanwhile, the knowledge economy plays a pivotal role in the socialization of individuals, the formation of the regulatory component of their economic activity using the introduction of social norms and rules in the range of value orientations of the individual. Studying the economic development of countries through a system of criteria that characterize quality of life (nutrition, health, safety, dwelling), E. J. Mishan in "The Economic Growth Debate" identifies the additional components of this system, namely: family, religion, traditions and customs ${ }^{26}$. The researcher argues the sustainability of morality of any moral code is necessary to man as the basic varieties of human communication (friendship, love,

${ }^{24}$ Парето В. Компедиум по общей социологии. Москва: Изд. дом ГУ ВШЭ, 2008. $511 \mathrm{c}$.

${ }^{25}$ Krugman P. The Concience of a Liberal. New York; London, 2007.

${ }^{26}$ Mishan E. J. The Economic Growth Debate. Allen \& Unwin, 1977. 280 p. 
mutual help, etc.) that satisfy social needs and needs for respect and selfexpression. E. J. Mishan says "The unrestricted continuation of the industrial expansion that we have been observing for two centuries throughout the Western world will lead to a slow but inevitable disintegration of the social order, to the collapse of all kinds of discipline and authority fixed in this order, and to the fact that people will find themselves in social and moral vacuum which is likely to be filled by a totalitarian state" 27 .

F. Hirsch in "Social Limits of Growth" drew similar conclusions. The scientist points out that "economists who have been engaged in economic growth for too long have paid very little attention to its moral fundamentals" ${ }^{, 28}$. According to F. Hirsch, qualities that have proven to be directly related to the "spirit of capitalism" and economic growth, namely: honesty, benevolence, restraint, obligation, all of them are among the values based on religious belief. Hirsch considers the growing dissatisfaction and glut with those "positional" benefits, which modern industry makes widely available, as other type of restrictions influencing economic growth. The rapid growth of similar benefits reduces their attractiveness to the average consumer worker that weakens motivation to work and reduces savings as a basis for investment. As a consequence, the economic growth is hindered. Naturally, values promoting economic habits maintain an attitude to work as a vital variable essential to ensure the growth that destroys them.

Findings of E. Mishan and F. Hirsch justify that at present, a society where social consensus is reached based on values shared by the majority of the population is more stable and inclined to progressive development. The knowledge economy transmits and transfers knowledge and gained experience from generation to generation, fixes sociocultural values in the individual consciousness leading to their adoption and transformation into an orientation component of the activities of economic entities ${ }^{29}$. In doing so, it creates conditions for the implementation of the management functions of the economic mechanism of the economic system, contributes to the achievement of economic policy goals.

${ }^{27}$ Mishan E. J. The Economic Growth Debate. Allen \& Unwin, 1977. 280 p.

${ }^{28}$ Hirsch F. Social Limits of Growth. Routledge, 1978. 232 p.

${ }^{29}$ Пилипенко Г. М. Інституціональні чинники державної та ринкової координації економічної діяльності: монографія. Д.: НГУ, 2012. 293 с. 
The knowledge economy influences the components of economic development, first, in the aspect of favouring economic increase as one of the factors of GDP growth and, second, as leverage over an opportunity to get education and improve population literacy, ensure environmental security and access to social benefits, creation of conditions for economic security and stability in society.

However, progressive development is impossible without the formation of its direct driving force - a person as a highly developed and harmonious personality possessing a sufficient level of human, cultural and social capital. The welfare of the people will be possible only when behaviour model necessary for this purpose will be consciously formed in the minds of citizens and become a leading social reflex.

As it is known, the cultural capital of a person forms sociocultural values and behaviour standards based on these values. The knowledge economy is the sphere where certain components of cultural capital are formed and the motivational factors of the economic behavioor of the subjects are established, which in the future act as regulators of their economic activity. It is crucial to accept those "rules of the game" which are foundation of economic and social order in society and to recognize them as legitimate for stable development.

Social capital is formed through training and education based on the achieved level of cultural and human capital. Acquisition of cultural values and acceptance of them as values orientations of activity promotes achievement of coordination effect and stability in a society. However, to make progressive changes in that sort of society, the activity and high social mobility of its members is essential. The ideological convictions of people based on a high level of education and intellectual qualities of the population play a major role in achieving the above goals. People must have core knowledge of the objective laws of economic, political and social development of society, the mechanisms of its changes and transformations. Due to education, the knowledge is formed and devolved to the next generations, as well as it is realized the process of creation and education of the future economic, scientific, cultural and political elite of the society which influences progressive development. Overall, develops personality and citizenship, establishes values of trust, equality, freedom, democracy, and thus creates components of social capital.

The above brings one to the conclusion that the knowledge economy is a factor in social change, as it develops the creative potential of each 
individual and, thus, acts as the most universal resource of civilization. Overcoming the old foundations of society is possible only because of the intellectual evolution of its members. A. Conte suggested about it confirming that "ideas rule the world and cause a ruckus in it. At the last, the whole social mechanism relies on people's opinion"30 that "intellectual evolution should be a priority as a basis of all human development: thy history of human spirit is at the head of history of society. Knowledge leads to predictions, predictions - to action, and action drives the need in knowledge" 31 .

Thus, the knowledge economy, forming qualitative characteristics of productive forces and creating conditions for implementation of managerial functions of economic mechanism, is one of the factors of economic growth and development of the postindustrial society. At the same time, due to the influence on other social systems, it promotes progressive socio-economic development. That position of education makes it one of the key determinants of the modernization of society and requires redouble attention to the parameters which ensure its effective functioning.

\section{CONCLUSIONS}

Today it is indisputable that the knowledge economy and the development of post-industrial society have a close interdependent relationship. The need of society in a man as a highly developed personality is realized through the establishment of the principle of humanism in relations between people, through the increasing importance of creative initiative. The knowledge economy has a leading role in the identification of society as a whole and of each individual in particular in specific historical conditions.

Knowledge production in a post-industrial society turns into a major national task. And countries with insight into the trends of world development have come to the fore of post-industrial civilization. The above is also about our country. The development of precise technologies based on informatization of work culture is our only chance not to fall down to the slums of the Third World; to rely on the main natural resource - intelligence and education of the people and to lead the government to support that sort of orientation to the best of ability. There

\footnotetext{
${ }^{30}$ Conte A. Course de philosofie positive. T. 1. P., 1830. 630 p.

${ }^{31}$ Ibid.
} 
are no problems more important than the development of the knowledge economy and the education of the master, even in the context of a crisis economy. These are the demands of a post-industrial society without which any steps towards development will be fruitless.

It is in the age of globalization when it is borne in upon that the knowledge economy is not a private matter, not the result of personal preferences but a social technology of human production, his abilities and skills the realization of which can lead the country to a new stage of development.

It is clear that the dynamics and transition rates of the economy in the post-industrial era depend to a large extent on the efficiency of the use of the results of creative activity of man. For this very reason, one of the major challenges, which needs a constant attention, is the creation of an effective system for production, protection, reproduction and use of intellectual potential. In particular, it is essential to lay the groundwork for the development of the economy sector where knowledge plays a decisive role. At the same time, it should be noted that the task to build postindustrial economy is impossible without the mechanism.

\section{SUMMARY}

The paper considers precondition for the development of the knowledge economy and its influence on the formation and development of postindustrial society as a paradigm of the modern development. It analyses the knowledge economy as a kind of economy where information and knowledge obtained on its basis play a pivotal role. The basis of that kind of economy is to create, spread and use knowledge to ensure competitiveness and innovation-driven development. The author studies the essence of the concept of postindustrial society where the top priority in the economy proceeded from predominant production of goods to the provision of services, research practice, organisation of the education system and improvement of the quality of life. It is considered information influence on the formation of the concept of the knowledge economy. The interrelation of human capital theory, intellectual capital theory and the knowledge economy is analysed. The author envisages the interconnection of the establishment of postindustrial society in the context of solving economic, social, environmental and cultural problems. It is proved that the knowledge economy is the most important factor of boost in personal income of those categories of the population which are forming new middle class today. 


\section{REFERENCES}

1. Тоффлер Э. Метаморфозы власти: Знание, богатство и сила на пороге XXI века / [Пер. с англ. науч. ред., предисл. П.С. Гуревича]. Москва: ООО «Издательство АСТ», 2002. 670 с.

2. Machlup F. The production and distribution of knowledge in the United States. Princeton: Princeton University Press, 1962. 416 p.

3. R. L. Katz. New York : Praeger, 1988. 168 p.

4. Тоффлер А. Футурошок. СПб : Лань, 1997. 464 с.

5. Індекс економіки знань. URL: file: C:/Users/User/Downloads/ ebrd-knowledge-economy-index.pdf (дата звернення 25.05.2019)

6. Демократизация глобальной экономики. Роль гражданского общества. Доклад центра изучения глобализации и регионализации университета г. Варвик: пер. на рус. яз. Л. Проскуряковой, 2003. 128 c. URL: http://warwick.ac.uk/fac/csgr/projects /russianreport.pdf.

7. Українське суспільство 1992-2012. Стан та динаміка змін. Соціологічний моніто-ринг / [За ред. В. Ворони, М. Шульги]. Київ: Інститут соціології НАН України, 2012. 348 с.

8. Белл Д. Грядущее Постиндустриальное общество: опыт социального прогнозирования / Перевод с английского Иноземцев В. Л. Изд. 2-ое, испр. и доп. Москва: Academia, 2004. 788 с.; Гальчинський А. С. Економічна методологія. Логіка становлення: Київ: «АДЕФ - Україна», 2010. 572 с.

9. Krugman P. R The Conscience of a Liberal. W.W. Norton \& Co., 2007. 352 p.

10. Гальчинський А. С. Економічна методологія. Логіка становлення: Київ: «АДЕФ - Україна», 2010. 572 с.

11. Брежнєва-Срмоленко О. В. Інтелектуальна складова в структурі елементів нової економіки. Актуальні проблеми економіки. 2010. № 3. С. 4-12.

12. Тоффлер О. Метаморфозы власти: знание, багатство и сила на пороге XXI века / Пер. с англ. Москва: Аспект Пресс, 2004. 400 с.

13. Белл Д. Грядущее Постиндустриальное общество: опыт социального прогнозиро-вания / Перевод с английского Иноземцев В. Л. Изд. 2-ое, испр. и доп. Москва: Academia, 2004. 788 с.

14. Кастельс М. Информационная эпоха. Экономика, общество и культура. Пер. с англ. под науч. ред О. И. Шкаратана. Москва: ГУ ВШЭ, 2000. 608 c. 
15. Тоффлер Э. Революционное богатство: как оно будет создано и как оно изменит вашу жизнь; [Пер. с англ. М. Султанова, И. Цыркун]. Москва: АСТ; АСТ МОСКВА; Профиздат, 2008. 596 с.

16. Грищенко I. М. Освіта та професійна підготовка фахівців у світлі Євроінтеграційних процесів. Актуальні проблеми економіки. 2010. № 7. С. 56-61.

17. Утюж I. Г. Освітній потенціал особистості: Монографія: Запоріжжя: ТОВ «КСК-Альянс», 2007. 147 с.

18. Bontis N. The strategies Management of Intellectual Capital and Organizational Knowledge. NY.: Oxford University Press, 2002. 740 p.

19. Mishan E. J. The costs of Economic Growth: Oxford University Press, 1993. $256 \mathrm{p}$.

20. Шкаратан О. И., Ильин В. И. Социальная стратификация России и Восточной Европы: сравнительный анализ. Москва: Изд. дом ГУ ВШЭ, 2006. 468 с.

21. Парето В. Компедиум по общей социологии. Москва: Изд. дом ГУ ВШЭ, 2008. 511 с.

22. Krugman P. The Concience of a Liberal. New York; London, 2007.

23. Mishan E. J. The Economic Growth Debate. Allen \& Unwin, 1977. $280 \mathrm{p}$.

24. Hirsch F. Social Limits of Growth. Routledge, 1978. 232 p.

25. Пилипенко Г. М. Інституціональні чинники державної та ринкової координації економічної діяльності: монографія. Д.: НГУ, 2012. $293 \mathrm{c}$.

26. Патнэм Р. Чтобы демократия сработала. Гражданские традиции в современной Италии. Москва: AdMarginam, 1996. 429 c.

27. Conte A. Course de philosofie positive. T. 1. P., 1830. 630 p.

\section{Information about the author: Matiuk T. V. $\mathrm{PhD}$ in Economics,}

Senior Lecturer at the Department of Economics and Entrepreneurship, Odesa I. I. Mechnikov National University 2, Dvorianska str., Odesa, 65000, Ukraine 